Acta Horticulturae et Regiotecturae 1

Nitra, Slovaca Universitas Agriculturae Nitriae, 2015, pp. 11-15

\title{
INFLUENCE OF MAGNETIC FIELD ON ONION SEED GERMINATION
}

\author{
Magdaléna VALŠíKOVÁ*, ${ }^{*}$, Jaroslav JEDLIČKA'1 Ivana MEZEYOVÁ1, Seda GULER ${ }^{2}$ \\ 'Slovak University of Agriculture in Nitra, Slovak Republic \\ ${ }^{2}$ Adnan Menderes University, Turkey
}

\begin{abstract}
Dynamics of onion seeds germination with different germinability and magnetic field influence with variable intensity on onion germinative activity was determined in trials. Amika F1 hybrid marked low germinative activity. On $21^{\text {th }}$ day after trial foundation it reached germinability of $34-46 \%$. Halftime of this germination was reached on fourth to fifth day after trial foundation. Exhibition variety had convenient germination activity, $70-91 \%$. Halftime of its germinability was reached on sixth to eighth day after trial foundation. On the base of submitted results there can be said that the seed with low germinative activity has faster initial start of germination. The seed with suitable germinative activity has more regular course of germinability from the beginning till the end of germination. Seeds of varieties Amika F1 and Exhibition achieved significantly lower germination in the radiation intensity of $20 \mathrm{mT}$ compared to other variants with the radiation intensity of $40 \mathrm{mT}, 55 \mathrm{mT}$ and the control one. Between the variants of $40 \mathrm{mT}$, $55 \mathrm{mT}$ and the control one the differences were not significant.
\end{abstract}

Keywords: Allium cepa, seeds, germination, magnetic radiation

Onion - Allium cepa, L., contains lot of components, which have protective (bioactive and chemo-protective) effect on human health. Many of them reduce risks of serious civilization diseases (Jedlička, 2012). First of all, these are antioxidant substances. In this group there belong, alongside some of vitamins, phenolic substances, mainly flavonoids, quercetin and kempferol, which act against heart and vascular diseases, they defend against the improvement of tumors and they have lot of other further effects (Keresteš, 2011). Some of onion sulfur compounds, like alicin, various S-metylcysteinsulfoxids, dialyldisulfids, izothiokyanats and other work as antioxidants as well. Onion is recommended in folk medicine as a cure for cold. Curative effects consist in bactericide and fungicide action of fytoncides content, which work as anti-inflammation medium (Valšíková et al. 2003). The onion helps in case of some appendix problems, influenza epidemics, it supports gall secretion and secretes of intestinal parasites (Uher a i., 2009). In the Slovak Republic, onion belongs to the most produced and consumed vegetables (Valšíková and Miklošová, 2013). In arable land, it takes $8.58 \%$ of all vegetable planted area and it takes part of $24 \%$ in vegetable production in tons. In consumption, onion takes the fourth place after tomatoes, cabbage and carrots (Meravá et al., 2014). Average consumption of onion is $8.5 \mathrm{~kg}$ per person and year (Valšíková and Uher, 2009).

The effect of magnetic field on seed germination was tried on tomatoes, beans and peas. We detected the increased dynamics of germination, initial growth of roots and aerial parts of the plants. In this work, we wanted to test the effect of magnetic radiation on onion seeds.

\section{Material and methods}

Amika and Exhibition onion varieties were used for experiment purposes. Amika is hybrid F1 with Italian origin. Its characteristic features are qualitative and resistant skin in dark bronze color. Bulbs are round-shaped and mediumsized. Amika is very suitable for longer storage. The seeds of Amika variety were obtained from unnamed agro-company in 2012. The expiration time of seeds was unknown. Seeds of this variety were stored by room temperature and its germinative activity was only $40 \%$. Exhibition variety was obtained by purchasing from Dutch company Bejo Zaden. It was packed by the producer with the date 11 - 2013 with term of expiration till $11-2015$. Informative germinability of this variety seeds moved from 80 to $85 \%$. It is a type with bigger bulbs with mild taste. It is recommended to consumption without long-term storage.

In laboratory conditions of the Department of Vegetable Production of the Slovak University of Agriculture in Nitra, there were established two equivalent trials on $18^{\text {th }}$ of July 2014 and they were run till $7^{\text {th }}$ of August 2014. Average temperature during the running of the trial was $25^{\circ} \mathrm{C}$. Seeds of onion varieties were laid on filtrate paper in Petri dishes. In every dish, as much as 100 seeds were put in four variants and three replications. After creation of wet conditions by watering of distilled water, the Petri dishes were covered by glass caps. Control variant stayed untreated by magnetic radiation, other variants were exposed to magnetic effect for 20 minutes 
Table 1 Variants of experiment

\begin{tabular}{|l||c|c|}
\hline $\begin{array}{l}\text { Variants } \\
\text { Varieties: AmikaF1 and Exhibition }\end{array}$ & $\begin{array}{c}\text { Experiment 1 } \\
\text { Petri dishes (laboratory) }\end{array}$ & $\begin{array}{c}\text { Experiment 2 } \\
\text { Petri dishes (laboratory) }\end{array}$ \\
\hline C - Control & $300 \mathrm{~s}$ & $300 \mathrm{~s}$ \\
\hline $\mathbf{2 0} \mathbf{~} \mathbf{T}$ & $300 \mathrm{~s}$ & $300 \mathrm{~s}$ \\
\hline $\mathbf{4 0} \mathbf{~} \mathbf{T}$ & $300 \mathrm{~s}$ & $300 \mathrm{~s}$ \\
\hline $\mathbf{5 5} \mathbf{~ T T}$ & $300 \mathrm{~s}$ & $300 \mathrm{~s}$ \\
\hline Total number of seeds & $1200 \mathrm{~s}$ & $1200 \mathrm{~s}$ \\
\hline
\end{tabular}

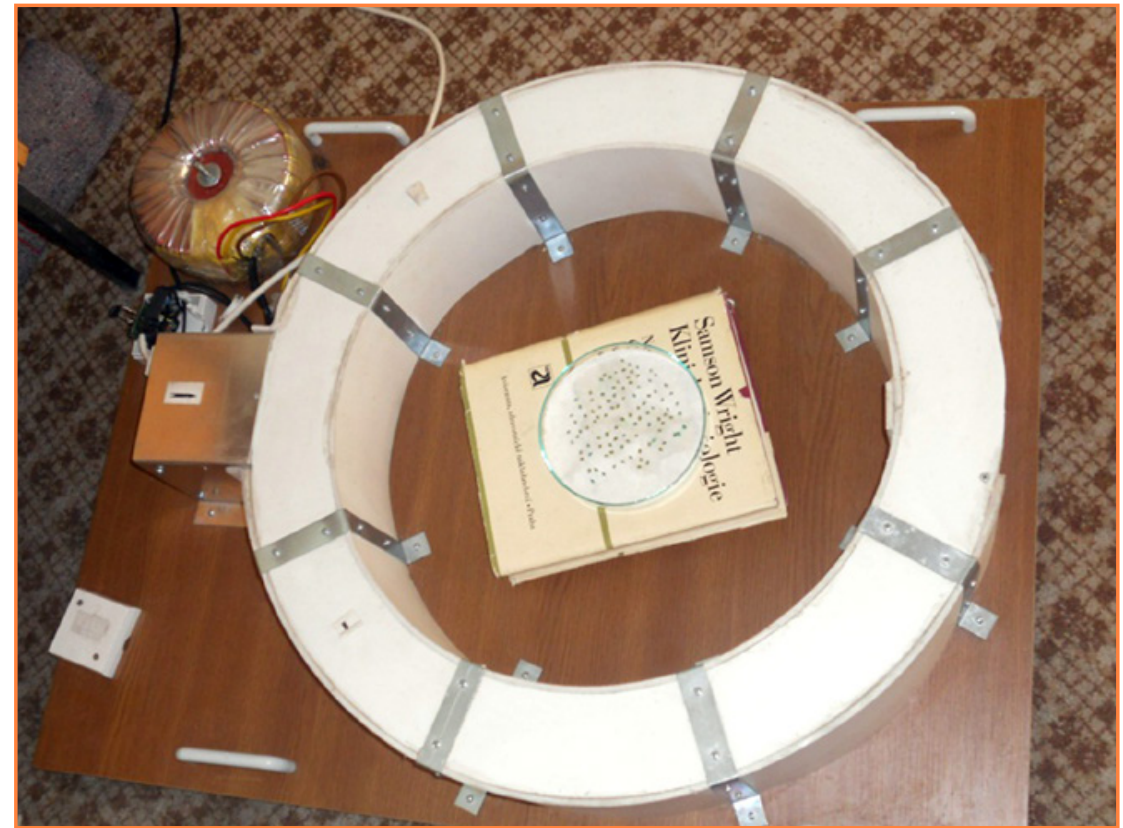

Figure 1 Electromagnetic inductor

by intensity of 20, 40 and $55 \mathrm{mT}$ (Table 1). Radiation was repeated 3 times in 2 days intervals. In case of all variants there was daily observed dynamics of germination: twice - at $8 \mathrm{a}$. m. and at 2 p. m. There were used 2400 seeds of onion from both varieties ( 2 trials $\times$ 4 variants $\times 3$ replications $\times 100$ ).

Magnetic field was created by electromagnetic induction coil with inside average $2 \mathrm{R}=55 \mathrm{~cm}$. Electromagnetic inductor (reactor) consists of conduit line conductor, voltage converter, magnetic induction measurer, conductor line wire to induction coil and from cylindered induction coil (Figure 1). It works according to the formula (Jedlička a i., 2012):

where:

$$
B=\frac{\mu_{0} \mu_{r} I z}{\sqrt{I^{2}+(2 R)^{2}}}
$$

$\mu_{0}$ - permeability of vacuum $4 \mu \cdot 10^{-7}$ $\left(\mathrm{m} \mathrm{kg} \mathrm{s} \mathrm{A}^{-2}\right)$ $\mu_{r}$ - relative permeability of background

I - electric current (A)

$z$ - number of induction coil scrolls

$I$ - length of induction coil (m)

$R$ - radius of induction coil (m)

\section{Statistical analysis}

The analysis of variance (ANOVA), the multifactor analysis of variance (MANOVA) and the multiple Range test were done using the Statgraphic Centurion XV (StatPoint Inc. USA).

\section{Results and discussion}

Trials were founded on observation of onion seeds germination dynamics, with convenient and inconvenient germinative activity. Another aim of the submitted work was to find out an influence of different intensity magnetic radiations on onion seeds germinability. In table 2 , the average values of germination activity from two observations at 8 a. m. and 2 p. $\mathrm{m}$. are noticed in case of both trials ( 1 and 2). Average values are featured, because there were not significant differences between results of replicate trials and between two observations during the one day. The standard deviation of the replicates ranged between 0 and 2 .

The hybrid Amika F1 had low germinative activity. On the $21^{\text {th }}$ day after trial foundation, it reached germinability of $34-46 \%$ (Table 2). Half-time of this germination activity was reached on the fourth - fifth day after trial establishment.

In case of the Exhibition variety, its final germinative activity moved in interval from 70 to $91 \%$ (Table 2), which is in accordance with minimal germinability requirement for $70 \%$, according to Collection of laws no. 58/2007, addition 2 (Valšíková and Kopec, 2010). Exhibition variety reached half-time of germinability on sixth to eighth day after trial foundation.

According to detection, there was found out, that the seed with low germinative activity has faster initial start of germination. In second halftime of germinative activity, the dynamics is slowed-down (Figure 2). On the other hand, the seed with suitable germinative activity has more regular course of germinability from the beginning till the final germination Figure 3).

In the experiment has not been expressed clearly conclusively influence of magnetic radiation on germination improving. In case of replicates there were not significant differences between germination of observed seed. Control variant and variants with $40 \mathrm{mT}$ and $55 \mathrm{mT}$ had significantly higher germination than the variant with dose od $20 \mathrm{mT}$ of magnetic radiation (Table 3 and 4). The highest $\%$ of germination of the 
Table 2 Average germinability in \% noticed in two trials, two measurements, two daily observations and three replicates

\begin{tabular}{|c|c|c|c|c|c|c|c|c|}
\hline \multirow{2}{*}{$\begin{array}{l}\text { Number of days } \\
\text { after seeding }\end{array}$} & \multicolumn{4}{|c|}{ Variety Amika F1 } & \multicolumn{4}{|c|}{ Variety Exhibition } \\
\hline & C-Control & $20 \mathrm{mT}$ & $40 \mathrm{mT}$ & $55 \mathrm{mT}$ & C- control & $20 \mathrm{mT}$ & $40 \mathrm{mT}$ & $55 \mathrm{mT}$ \\
\hline 3 & 6 & 8 & 7 & 6 & 5 & 5 & 6 & 7 \\
\hline 4 & 19 & 15 & 16 & 17 & 17 & 12 & 13 & 21 \\
\hline 5 & 24 & 18 & 22 & 21 & 26 & 16 & 20 & 26 \\
\hline 6 & 24 & 20 & 23 & 23 & 32 & 23 & 26 & 33 \\
\hline 7 & 28 & 22 & 28 & 27 & 46 & 32 & 38 & 45 \\
\hline 8 & 29 & 25 & 28 & 28 & 56 & 45 & 46 & 54 \\
\hline 9 & 30 & 26 & 30 & 28 & 59 & 52 & 53 & 60 \\
\hline 10 & 31 & 27 & 32 & 31 & 70 & 58 & 57 & 64 \\
\hline 11 & 32 & 27 & 32 & 32 & 72 & 59 & 62 & 65 \\
\hline 12 & 33 & 28 & 33 & 32 & 75 & 61 & 67 & 67 \\
\hline 13 & 33 & 28 & 35 & 35 & 77 & 62 & 69 & 70 \\
\hline 14 & 35 & 29 & 36 & 36 & 78 & 63 & 72 & 70 \\
\hline 15 & 35 & 29 & 37 & 37 & 81 & 64 & 74 & 72 \\
\hline 16 & 35 & 30 & 39 & 38 & 81 & 66 & 77 & 74 \\
\hline 17 & 35 & 31 & 40 & 38 & 82 & 67 & 80 & 75 \\
\hline 18 & 36 & 32 & 42 & 39 & 83 & 68 & 82 & 75 \\
\hline 19 & 37 & 33 & 44 & 39 & 84 & 68 & 85 & 77 \\
\hline 20 & 38 & 34 & 45 & 39 & 85 & 68 & 88 & 78 \\
\hline 21 & 40 & 34 & 46 & 39 & 85 & 70 & 91 & 78 \\
\hline
\end{tabular}

three variants with treated seed by a magnetic field was at variant with $40 \mathrm{mT}$ (Figure 4). However, between control variants and variants treated with magnetic radiation of value $\mathrm{mT}$ 40 and $\mathrm{mT} 55$ was not found significant difference (Table 3 and 4).

Similar results were obtained by Bachárová (2013) by evaluation of electromagnetic field influence on tomato seed germination. Indeed, she found out that the various doses of $\mathrm{mT}$ had influence on sprits and roots length. Authors Vashisth, Joshi and Singh (2012) studied the water distribution during germination in sunflower seeds exposed to magnetic field. They found that hydration water fractions in magnetically exposed seeds may be responsible for quicker germination and early seedling vigor in sunflower.

Martínez, Pacheco, Aguilar, Pardo and Ortiz (2014) tested improving of the physiological quality of aged broccoli seed in a variable magnetic field. The variable magnetic field effects depended on the seed aging time, resulting in positive,

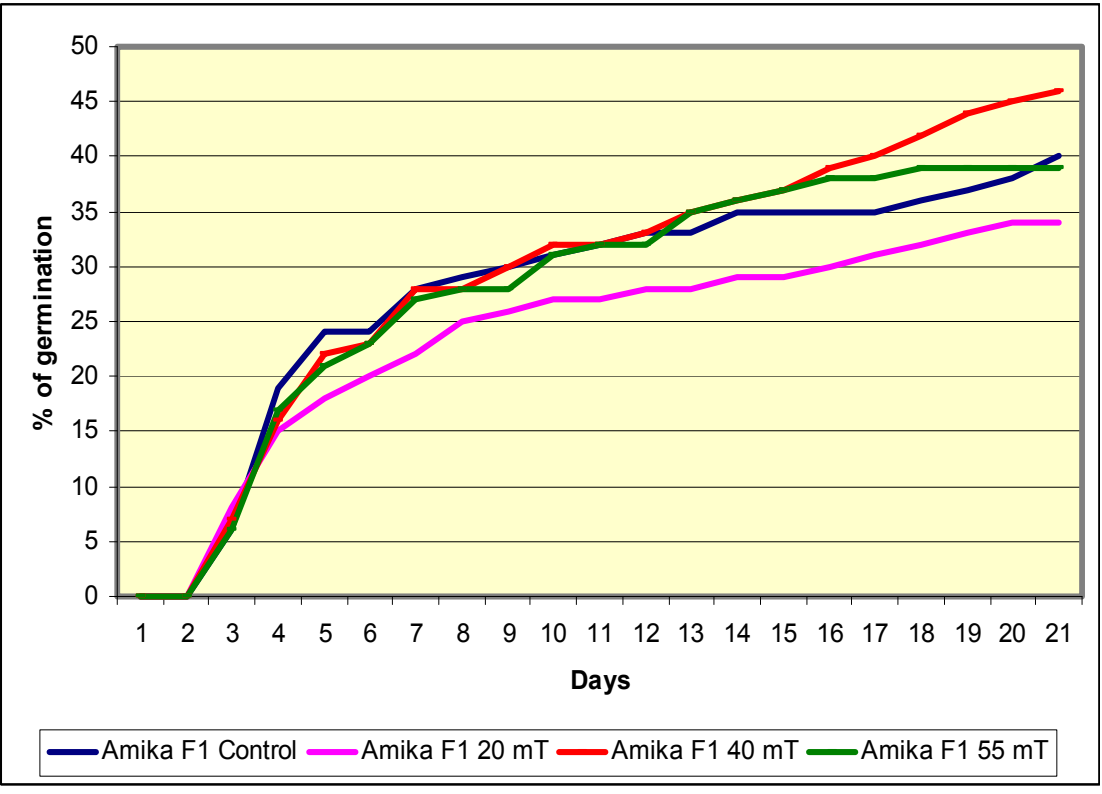

Figure 2 Dynamics of onion seed germinability, Amika F1 variety

negative and null outcomes in vigor variables. Matwijczuk, Kornarzyński and Pietruszewski (2012) found out the effect of magnetic field on seed germination and seedling growth of sunflower.
In experiments (Flórez, Carbonell and Martínez, 2007), the maize seeds were magnetically exposed to one of two magnetic field strengths, 125 or $250 \mathrm{mT}$ for different periods of time. Treated plants grew higher 


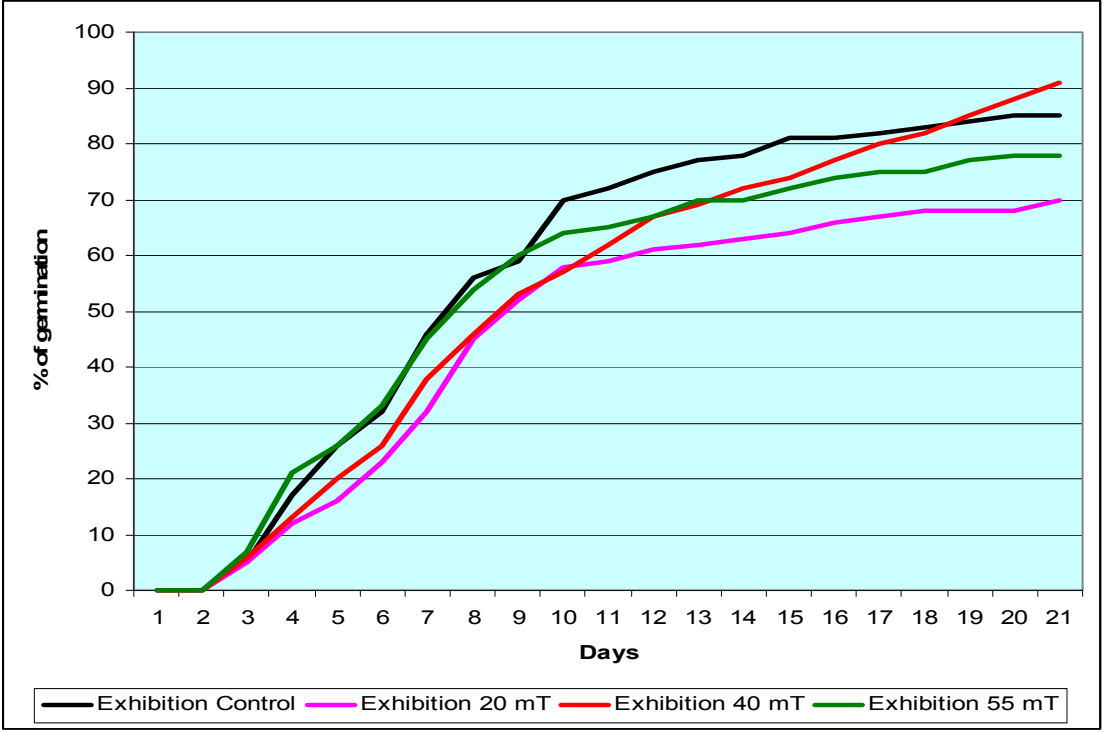

Figure 3 Dynamics of onion seed germinability, Exhibiton variety and heavier than control ones. The greatest increases were obtained for plants continuously exposed to 125 or $250 \mathrm{mT}$.

\section{Conclusions}

The hybrid Amika F1 with low germinative activity reached halftime of germinability on the fourth to fifth day after the trial foundation. The Exhibition variety had convenient germinability and half-time of germinative activity reached on sixth to eighth day after the trial establishment. Faster initial start of germination was noticed in case of onion seeds with inconvenient germinability. The seeds with suitable germinative activity have more regular course of germinability

Table 3 Multiple Range Tests for germination of onion in \% by Amika F1 variants Method: 95.0 percent LSD

\begin{tabular}{|c|c|c|c|c|}
\hline Amika F1 variants & Count & LS Mean & LS Sigma & Homogeneous Groups \\
\hline $20 \mathrm{mT}$ & 57 & 26.0526 & 1.11861 & $x$ \\
\hline C-control & 57 & 30.5789 & 1.11861 & $X$ \\
\hline $55 \mathrm{mT}$ & 57 & 31.1053 & 1.11861 & $x$ \\
\hline $40 \mathrm{mT}$ & 57 & 31.4737 & 1.11861 & $x$ \\
\hline Contrast & Sig. & Difference & +/- Limits & - \\
\hline $20-40 \mathrm{mT}$ & * & -5.42105 & 3.11741 & - \\
\hline $20-55 \mathrm{mT}$ & * & -5.05263 & 3.11741 & - \\
\hline $20 \mathrm{mT}$ - C-control & * & -4.52632 & 3.11741 & - \\
\hline $40-55 \mathrm{mT}$ & - & 0.368421 & 3.11741 & - \\
\hline $40 \mathrm{mT}$ - C-control & - & 0.894737 & 3.11741 & - \\
\hline $55 \mathrm{mT}$ - C-control & - & 0.526316 & 3.11741 & - \\
\hline
\end{tabular}

*denotes a statistically significant difference

Table 4 Multiple Range Tests for Exhibition.Germination in \% by Exhibition variants Method: 95.0 percent LSD

\begin{tabular}{|c|c|c|c|c|}
\hline Exhibition variants & Count & LS Mean & LS Sigma & Homogeneous Groups \\
\hline $20 \mathrm{mT}$ & 57 & 50.4737 & 3.12947 & $X$ \\
\hline $40 \mathrm{mT}$ & 57 & 58.2105 & 3.12947 & $X X$ \\
\hline $55 \mathrm{mT}$ & 56 & 58.3393 & 3.15729 & $X X$ \\
\hline C-control & 57 & 62.4912 & 3.12947 & $X$ \\
\hline Contrast & Sig. & Difference & +/- Limits & - \\
\hline $20-40 \mathrm{mT}$ & * & -7.73684 & 8.72165 & - \\
\hline $20-55 \mathrm{mT}$ & * & -7.8656 & 8.7605 & - \\
\hline $20 \mathrm{mT}$ - C-control & * & -12.0175 & 8.72165 & - \\
\hline 40-55 mT & - & -0.128759 & 8.7605 & - \\
\hline $40 \mathrm{mT}$ - C-control & - & -4.2807 & 8.72165 & - \\
\hline 55 mT - C-control & - & -4.15194 & 8.7605 & - \\
\hline
\end{tabular}

* denotes a statistically significant difference 


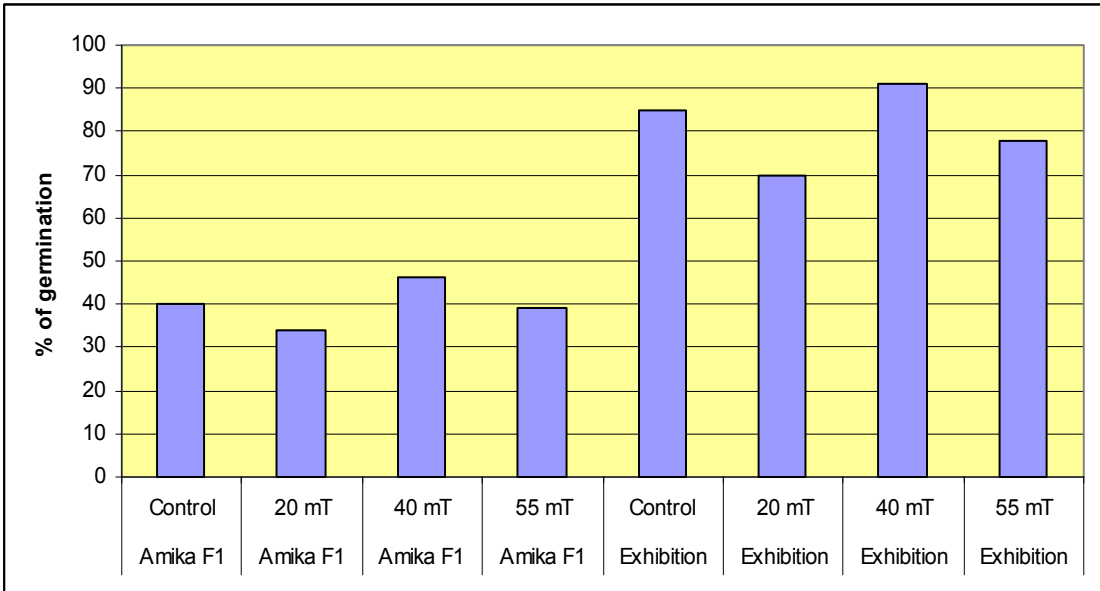

Figure 4 Influence of magnetic radiation intensity on onion seed germination activity

from the beginning till the final germination. The lowest germination was observed in variant $\mathrm{mT}$ with $20 \mathrm{mT}$ and the highest in variant with $40 \mathrm{mT}$, when the influence of magnetic radiation on onion seed germination was evaluated. Between the variants with $40 \mathrm{mT}, 55 \mathrm{mT}$ and the control one, the differences were insignificant.

\section{References}

BACHÁROVÁ, B. 2013. Vplyv magnetického pola na klíčenie rajčiaka. Diplomová práca, Nitra : SPU, 2013, 49 s.

FLÓREZ, M. - CARBONELL, M. V. - Martínez, E. Exposure of maize seeds to stationary magnetic fields and effects on germination and early growth. In Environmental and Experimental Botany, vol. 59, 2007, no. 1, p. 68-75.
JEDLIČKA， J. a i. 2012. Optimalizácia zakoreňovania odrezkov jednoročného dreva viniča hroznorodého pôsobením nízkofrekvenčného magnetického pol'a. Nitra : SPU, 2012. 8 s.

JEDLIČKA, J. 2012. Ovocie a zelenina pri prevencii a liečbe ochorení ludí. Nitra : SPU, 2012, 190 s. ISBN 978-80-552-0859-6.

KERETEŠ, J. a i. 2011. Zdravie a výživa ludí. Bratislava : CAD Press, 2011, 1037 s. ISBN 978-80-88969-57-0.

MARTÍNEZ, F. R. - PACHECO, A. D. AGUILAR, C. H. - PARDO, G. P. - ORTIZ, F. M. 2014. Effects of magnetic field irradiation on broccoli seed with accelerated aging. In Acta Agrophysica, vol. 21, 2014, no. 1, pp. 63-73.

MATWIJCZUK, A. - KORNARZYŃSKI, K. PIETRUSZEWSKI, S. 2012. Effect of magnetic field on seed germination and seedling growth of sunflower. In International Agrophysics, vol. 26, 2012, no. 3, pp. 271278. ISSN (Print) 0236-8722.
MERAVÁ, E a i. 2014. Zelenina - situačná a výhl'adová správa k 31. 12. 2013. VÚEPP, MPRV SR, roč. 18, 2014, júl, s. 50. ISSN 1338-8010.

UHER, A. a i. 2009. Zeleninárstvo - polné pestovanie. Nitra : SPU, 2009, 212 s. ISBN 978-80-552-0199-3.

VALŠÍKOVÁ, M. - KOPEC, K. 2010. Semenárstvo zeleniny a kvetín. Nitra : SPU, 2010, 131 s. ISBN 978-80-552-0487-1.

VALŠÍKOVÁ, M. - UHER, A. 2009. Situation of vegetables production from the aspect of the Science and Research in Slovak Republic. In Acta horticulturae et regiotecturae, vol. 12, 2009, supplement, pp. 232-237.

VALŠÍKOVÁ, M. - HRIČOVSKÝ, I. - HRONSKÝ - JAKÁBOVÁ, A. 2003. Rok v záhrade jar. Bratislava : Foxi, 2003, 142 s. ISBN 80-7147-293-X.

VALŠíKOVÁ, M. - MIKLOŠOVÁ, P. 2013. Pestovanie cibul'ovej zeleniny v Slovenskej republike. In Zahradnictví, roč. 12, 2013, č. 7, s. 16-17. ISSN 1213-7596.

VASHIST, A. - JOSHI, D. K. - SINGH, R. 2012. Water Distribution during Germination in Sunflower (Helianthus annus L.) Seeds Exposed to Magnetic Field. In Journal of Agricultural Physics, vol. 12, 2012, no. 2, pp. 162-169. ISSN 0973-032X. 